\title{
癌化学療法による患者の栄羑状態の変化に関する検討
}

\author{
外 崎 明子*1・数 間 恵 子*2・石 黒 義 彦*3
}

\section{A Study of Changes in the Nutritional Status of Patients Receiving Cancer Chemotherapy}

\author{
Akiko Tonosaki*1, Keiko Kazuma*2 and Yoshihiko Ishiguro*3 \\ *1 Former Toranomon Hospital \\ *2 School of Allied Health Sciences, Tokyo Medical and Dental University, \\ lecturer $\cdot$ Nursing Research and Development Station \\ ${ }^{* 3}$ School of Nursing, Chiba University
}

\begin{abstract}
Abstact
In an attempt to find a method for effective nursing support which would maintain a favorable nutritional status in patients receiving chemotherapy, the nutritional status of 15 patients with lung cancer receiving cisplatin therapy was evaluated, and the factors influencing their status were studied.

(1) Nutritional status was evaluated in terms of 7 indicators: body weight, skinfold thickness, arm muscle circumference, grip strength, hemoglobin level, serum total protein and serum albumin. Among these, skinfold thickness proved to be the most sensitive indicator of the changes in nutritional status of cancer patients during chemotherapy .

(2) Multiple regression analysis revealed that skinfold thickness was influenced by dietary intake, which in turn was related to nausea, vomiting, trait anxiety level estimated by STAI and maximum body temperature associated with infection.

(3) It was concluded that the following nursing interventions are significant for maintenance of favorable nutritional status for cancer patients during chemotherapy. First, periodic evaluation of their nutritional status by anthropometric measurements is necessary. Secondly, efforts should be made to reduce nausea and vomiting, to reassure patients with severe anxiety so that they become mentally stable, and to motivate the patients to perform self-care for prevention of infection, thereby achieving a sufficient dietary intake.
\end{abstract}

\section{要 旨}

本研究はシスプラチンを投与される肺癌患者15名を対象に, 治療中の良好な栄養状態を 保持するための看護援助方法を検討する目的で, はじめに患者の栄養状態を評価し, 次い でその影響因子を明らかにした。

(1) 栄養状態の評価には, 体重, 皮下脂肪厚, 上腕筋囲, 握力, 血色素量, 血清総蛋白抒 よび血清アルブミンの 7 指標を用いたが, 皮下脂肪厚が癌化学療法中の栄養状態の変化の 指標として最も鋭敏であることが判明した。

*1 前国家公務員等共済組合連合会虎の門病院 $* 2$ 東京医科歯科大学医学部保健衛生学科非常勤講師・看 護研究開発センター $* 3$ 千葉大学看護学部 
(2) 皮下脂肪厚の変動には食事の摂取量が影響し, 食事の摂取量には嘔気・嘔吐, 特性不 安得点, 感染による発熱の最高值が関連していることが重回帰分析より明らかになった.

(3)したがって, 癌化学療法中の患者の栄養状態を良好に保持するためには, 看護援助方 法として, 第一に定期的な身体計測により栄養状態を評価すること, 第二に嘔気・嘔吐を 軽减するように努め, 不安の強い患者に対しては精神的安定が得られるように援助し, 感 染予防に対する患者の自己管理能力が高まるように働きかけ，これらにより十分な食事摂 取ができるよらにすること, が必要であるとの結論が得られた.

\section{I . はじめに}

近年発達のめざましい癌化学療法の中でもシ スプラチン(以下，CDDPという) は睪丸腫瘍, 卵巣腫瘍や肺癌など多くの癌に対して有効性が 認められている1). しかし際立った有効性と共 に副作用も強く, 腎毒性, 消化器毒性や神経毒 性が顕著な薬剂である.とりわけ嘔気・嘔吐は 患者にとって最も苦痛の強い副作用であり2) こ のために患者が治療の継続を拒否する場合があ る. 最近ではプリンペランの大量投与などで $\left.{ }^{3)}, 4\right), \mathrm{CDDP}$ 投与後の急性の嘔気・嘔吐はコン トロールされつつあるが，投与後数日間にも及 ぶ嘔気や食欲不振はいまだ完全には解決してい ない。これらの症状は栄養状態に悪影響を及ぼ すため, 免疫機能の低下により感染をおこし， さらに栄養状態を悪化させるという悪循環の危 険性がある5)6)。 また栄養状態を良好に保つこ とは治療の効果や安全性を高め, 合併症予防の ために大切であるとされている6) 9).

そこで本研究ではまず化学療法(以下，化療 という)を受ける肺癌患者の栄養状態を継続的 に評価し, 次いで化療前後で患者の栄養状態に 変化を及汸すと考えられる因子の実態を明確に し，栄養状態との関連を調べた，そしてこれよ り化療を受ける患者の栄養状態を良好に保持す るための看護援助方法を検討することとした. な抒, 栄養状態は身体計測, 握力測定, 血液拈 よび生化学検査のデータによって評価した.

\section{II. 研究方法}

\section{1. 対象}

昭和 63 年 5 月から 9 月に国立がんセンター呼 吸器内科に入院した肺癌患者のらち, 『厚生省
がん研究助成金「がんの集学的治療の研究」班, 肺がんグループ』によるプロトコールに従って, CDDPを含む治療が実施された男性10名, 女性 5 名, 計15名を対象とした。平均年齢は男性 60.3 歳, 女性62.8歳で, 病期は I ・II期はなく, III 期が 5 名, $\mathrm{IV}$ 期が10名であった.

\section{2. 栄養状態評価指標の測定方法}

栄養状態は看護実践の場で繰り返し実行可能

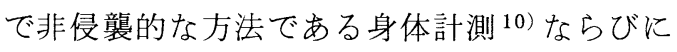
病歴調査などによって資料をえ, 評価すること とした.

対象患者は化療前に医師から治療の効果と副 作用に関する説明がなされ, その後看護婦によ り病棟にて作成されたパンフレットに従って化 療に対するオリエンテーション 11 が実施され た。そして身体計測は事前に対象患者から研究 に対する承諾をえ，国立がんセンターにおいて 通常化療を受けている患者に対して実施される 看護を著者が提供しながらデータを得た。

栄養指標として体重, 皮下脂肪厚, 上腕筋囲, 握力, 血色素量, 血清総蛋白括よび血清アルブ ミン(以下, $\mathrm{Hb}, \mathrm{TP}, \mathrm{Alb}$ という)の 7 項目を選 んだ.資料の収集は化療前, 化療後 1 週, 2 週, 3 週の 4 回行った.

皮下脂肪厚は栄研式皮下脂肪厚計で上腕三頭 筋部および肩胛骨下端部の 2 か所を測定し, 測 定值の和を脂肪量の指標とした. 尚, 検者間で の誤差をなくすため, 測定は著者がすべて行っ た. 上腕筋囲 $(\mathrm{AMC})$ は, 上腕三頭筋部皮下脂 肪厚 $(\mathrm{TSF})$ と巻き尺にて計測した上腕囲 $(\mathrm{AC})$ を用いて算出し $(\mathrm{AMC}=\mathrm{AC}-3.14 \times \mathrm{TSF})$ 筋蛋 白量の指標とした ${ }^{7)}{ }^{12}$. 同じく骨格筋肉量の 指標である握力は, ツッミ式握力計を用いて測 定し, 連続測定による易疲労性の評価も加味す 
るために ${ }^{13)}$ 左右計10回を連続測定し, その平 均值を採用した。

$\mathrm{Hb}, \mathrm{TP}, \mathrm{Alb}$ の值はカルテより収集した。

\section{3 . \%標準値の算出}

体重, 皮下脂肪厚, 上腕筋囲および握力は性 別・年齢によって標準值が異なるため, 患者の 計測值の評価にあたっては, 患者と同性・同年 齢層の一般健康人の標準值に対する比率 $(\%$ 標 準值)で示した。標準值は体重 ${ }^{14)}$ および皮下脂 肪厚 ${ }^{15)}$ では厚生省による国民栄養調査の結果 を, 握力は文部省による体力運動能力調查結果 ${ }^{16)}$ を用いた。 上腕筋囲は対象患者と同年齢層の標 準值が発表されていないため, 昭和63年 8 月に 千葉県Y町における住民検診において160名の 計測を実施して上腕筋囲を算出し, この平均值 を『標準上腕笳囲』とし，表 1 に示した。なお， $\mathrm{Y}$ 町住民検診で同時に測定した体重㐨よび皮下 脂肪厚の平均值は，各年齢階級層において国民 栄養調査の結果と有意な差はみられなかった。

\section{4 . 栄養状態変化因子の調査}

CDDP投与に伴なら栄養状態の低下に関連す ると考えられる主要な変化因子を図 1 に示した. まず性別, 年齢, 病期, 精神状態などの背景因

\section{表 1 標準上腕筋囲}

\begin{tabular}{cc}
\hline 男 & 性 \\
\hline 年齢階級 (歳) & 上腕筋囲 $(\mathrm{cm})$ \\
\hline $40-59$ & 24.8 \\
\hline $60-79$ & 22.7 \\
\hline 女 & 性 \\
\hline 年齢階級 (歳) & 上腕筋囲 $(\mathrm{cm})$ \\
\hline $50-59$ & 20.3 \\
\hline $60-69$ & 19.7 \\
\hline
\end{tabular}

子をもつ患者にCDDPが投与されると，身体各 藏器に障害がおこる．この中で特に栄養状態の 低下と結びつきやすいものとして，(1)嘔気・嘔 吐といった消化器障害による食事量の低下, (2) 副作用の合併や体力の喪失感などによる不安の 増大, (3)骨䯣抑制に伴ら感染率の増加と発熱に 注目し，これらの因子について化療前から化療 後 3 週までを観察した。な䄈精神状態は状態— 特性不安尺度 (STAI 法) ${ }^{17)}$ を用いて化療前の特 性不安の程度を評価した。 そして栄養指標の変 化に対する変化因子の影響をみるために重回帰 分析を実施した。

なお統計処理には，パーソナルコンピュータ 統計プログラムパッケージ “HALBAU”を利 用した。

\section{III. 結果}

調査期間内に 15 名の患者が受けた化療は計 23 クールであった．各クールに該当する患者数は 第 1 クールが 8 名, 第 2 クールが11名, 第 3 クー ルが 3 名, 第 4 クールが 1 名であった. 1 クー ルを 1 例とし，のべ23例について分析した.

\section{1 . 栄養指標の変動}

\%標準体重の変動を図 2 に示した。男性では 化療前後に大きな変動はなく, 破線で示した死 亡の 1 事例では化療前より\%標準体重が低く, 3 週以後急速に低下し，51日目に死亡した。女 性は男性に比べ，やや低下傾向がみられ，特に 化療中に死亡した 1 事例は化療前より\%標準体 重が70\%未満と極端に低く，化療開始後わずか 21日目に死亡している.

さらに男女別に各測定時期の\%標準体重の平

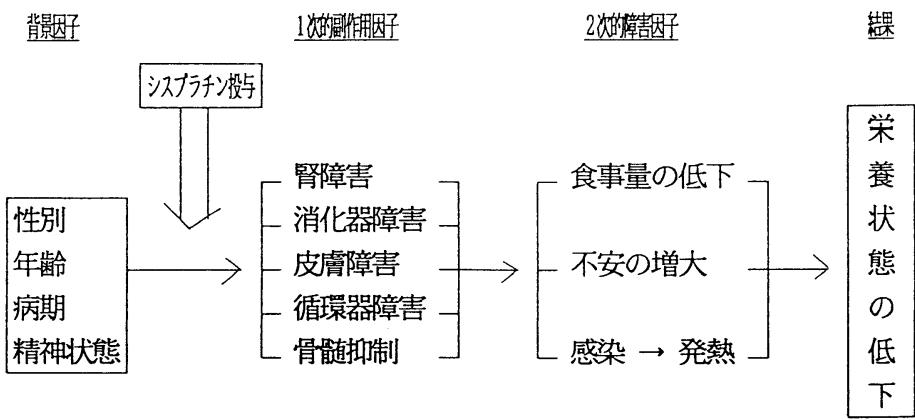

図 1 栄養状態に関わる主要変化因子 

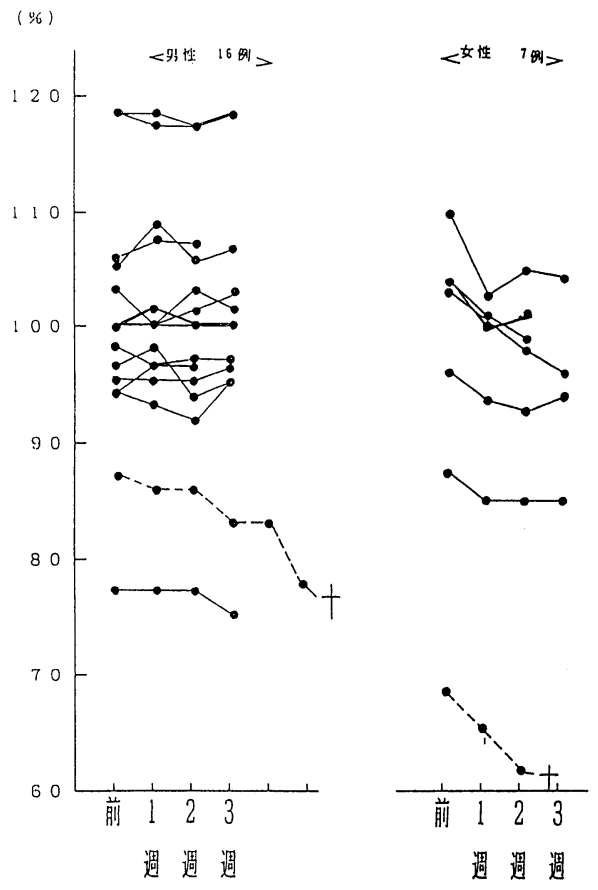

図 $2 \%$ 標準体重の変動 $(+$ : 死亡事例 $)$

均値を算出し(顕著に逸脱した值を示した女性 死亡事例は除外)，化療前後の差があるかどう かを調べ，表 2 に示した．男性では化療前後の 変動に有意差は認められなかったが，女性では 1 週後, 2 週後および 3 週後のいずれの時期も 化療前と比較し有意な減少が認められた。

図 3 亿示した\%皮下脂肪厚の変動は, 女性で は全例とも化療前\%皮下脂肪厚が100\%未満で, 開始後経時的に減少し, 男性より化療による皮 下脂肪厚の減少が著しいことが示された. 特に 女性の死亡事例は，化療前が $35 \%$ ，以後 $28 \%$ ，

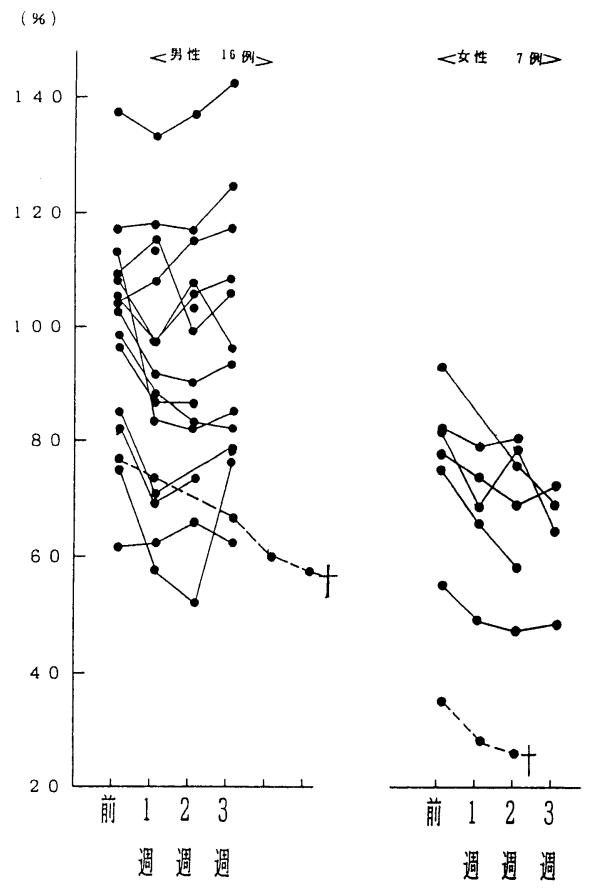

図 $3 \%$ 皮下脂肪厚の変動 $(+:$ 死亡事例 $)$

$26 \%$ と減少していた。平均\%皮下脂肪厚 (女性 死亡事例を除く)は，表 2 に示したように，女 性は化療前より80\%未満で，3 週後には63.3\% と低い值となった。 そして男性では，1週およ び 2 週後に, 女性では 1 週, 2 週, おちよび 3 週 後に化療前と比べてそれぞれ有意な低下が認め られた。

図 4 に示した\%上腕筋囲の変動は, 男女とも 化療前後で有意な変動は認められなかったが, 死亡事例は際立って低い值をとり，その減少も 急激であった。平均 $\%$ 上腕筋囲 (女性死亡事例

表 2 各測定時期の身体測定値の変動

\begin{tabular}{|c|c|c|c|c|c|c|}
\hline \multirow[b]{2}{*}{ 化療 } & \multicolumn{2}{|c|}{ 平均\%標準体重 } & \multicolumn{2}{|c|}{ 平均\%皮下脂肪厚 } & \multicolumn{2}{|c|}{ 平均 $\%$ 上腕筋囲 } \\
\hline & 男性 $(\mathrm{n}=16)$ & 女性 $(\mathrm{n}=6)$ & 男性 $(\mathrm{n}=16)$ & 女性 $(\mathrm{n}=6)$ & 男性 $(\mathrm{n}=16)$ & 女性 $(\mathrm{n}=6)$ \\
\hline 前 & $99.6 \pm 10.01$ & $\begin{array}{c}100.7 \pm 7.34 \\
*\end{array}$ & $98.8 \pm \frac{*}{*}{ }^{*}{ }^{*}$ & $\begin{array}{c}78.0 \pm 11.66 \\
*\end{array}$ & $94.9 \pm 6.70$ & $110.8 \pm 5.21$ \\
\hline 1 週 & $99.9 \pm 10.19$ & $96.6 \pm 6.53$ & $91.7 \pm 21.36$ & $67.4 \pm 9.83$ & $94.7 \pm 8.42$ & $111.0 \pm \frac{3.85}{* *}$ \\
\hline 2 週 & $99.7 \pm 10.30$ & $97.0 \pm 6 . \overline{51}$ & $94.3 \pm 21.65$ & $68.5 \pm 12.08$ & $95.4 \pm 7.25$ & $109.5 \pm 3.55$ \\
\hline 3 週 & $99.2 \pm 11.19$ & $94.8 \pm 6.76$ & $97.0 \pm 22.67$ & $63.3 \pm 9.26$ & $92.4 \pm 6.60$ & $111.8 \pm 3.27$ \\
\hline
\end{tabular}

$* \mathrm{p}<0.05 \quad * * \mathrm{p}<0.01$ 


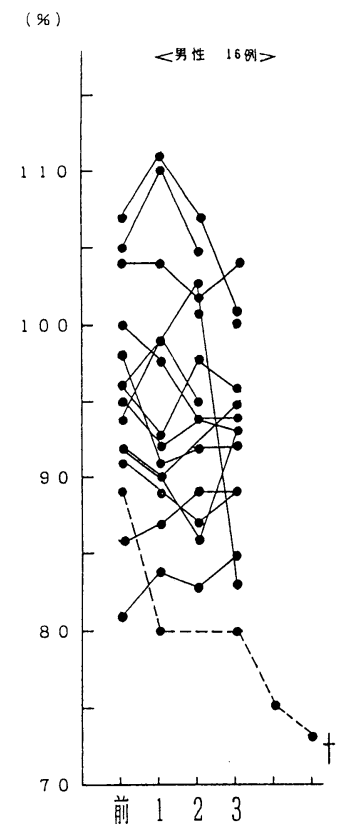

遏週遏
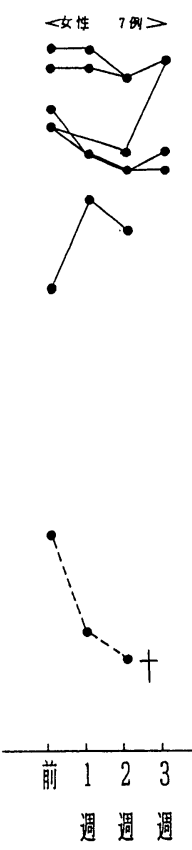

図 $4 \%$ 上腕筋囲の変動 $(+$ : 死亡事例 $)$

を除く)は，表 2 に示したように女性で 1 週と 2 週の間に有意な変動があった。

\%握力は男女とも化療前後で有意な変動は示 さなかったが，握力と上腕笳囲は各測定時期で, 相関係数 $0.49 \sim 0.64(\mathrm{p}<0.05)$ のかなりの相関 が認められた。

$\mathrm{Hb}$ の変動は化療後 2 週を最低值とした明ら かな $\mathrm{V}$ 字型となり，単に栄養状態の低下による だけでなく，骨髄抑制の影響も強いと考えられ
た、このほかTPおよびAlb は死亡事例を除い ては有意な変動は示さなかった。

\section{2. 栄養状態変化因子の実態}

前述した女性死亡事例は化療後 6 日に喀血が あり,「気管支動脈塞栓術」などの治療をうけ ているため, 化療以外の影響も考兄られ以後の 分析からは除外した。

食事摂取量は，全量摂取を 100 として 3 食の 平均摂取量を算出し， 1 日の摂取量を把握した. そして化療前の平均摄取量が個々で違らため, 化療後平均摄取量を化療前平均摄取量に対する 比率で表わし，それを「\%食事摂取量」とする こととした.

図 5 に\%食事摂取量の推移を男女別の平均値 で示した。男性では10日頃には化療前の食事量 に回復しているが，女性では食欲不振が持続し， 20 日後でも化療前の $2 / 3$ 程度であった. 全期間 を通じて女性のほうが\%食事摂取量が有意に少 ない傾向がみられた $(\mathrm{p}<0.05)$.

嘔気はCDDP投与後全例に認められ, 嘔気を 訴えた日数は男性では最長 11 日間, 平均 3.4 日 間，女性では最長 9 日間，平均6.2日間であり， 女性のほうが長い傾向であった $(\mathrm{p}<0.05)$. 次 に嘔吐の発生率は男性では $44 \%$ 女性では $100 \%$ であったが, 観察期間内での累積嘔吐回数の平 均は, 男女間に有意な差は認められなかった。

化療の 1 次的な副作用である骨䯣抑制により， 化療後 2 週目頃に白血球数が最低值をとる場合 が多く, 対象患者の約 6 割は白血球数が $3000 / \mathrm{mm}^{3}$

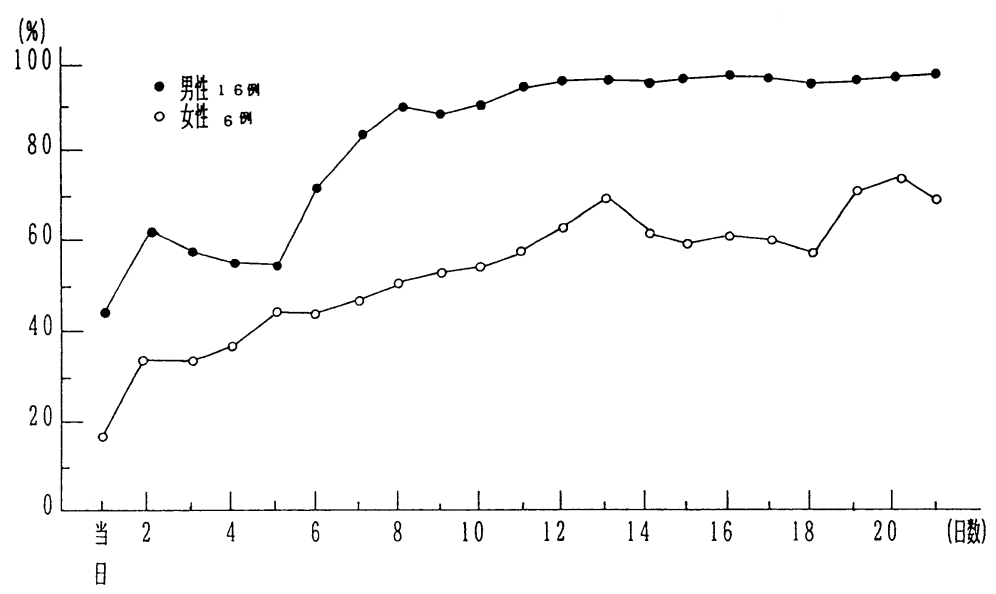

図 $5 \%$ 食事摂取量の推移 
を下回った．このため感染して $37^{\circ} \mathrm{C}$ 以上に発熱 した者が男性では 6 例，女性では 4 例にみられ たが, 発熱の発生率には性差は認められなかっ た $\left(\mathrm{X}^{2}=1.497, \mathrm{p}<0.05\right)$. また発熱の最高値は $39.6{ }^{\circ} \mathrm{C}$ にで上昇した者もあり, 平均では 38.2 ${ }^{\circ} \mathrm{C}$ であった. 発熱の日数は男性で平均 2.1 日, 女性で1.3日であり, 発熱の最高值, 発熱の日 数とも男女間に有意な差は認められなかった。

特性不安得点は 50 点以上のものはなく, 平均 得点と標準偏差は, 男性は $36.1 \pm 5.86$ 点, 女性 は39.0点 \pm 7.77 点で, 有意な男女差は認められ なかった。

\section{3. 重回帰分析の結果}

栄養指標に対する各栄養状態変化因子の影響 の大きさを比較するために栄養指標を基準変数 とし, 栄養状態変化因子を説明変数として重回 䚻分析(変数増減法, F in/out 2)を行った.

7 つの栄養指標の中で化療前後で男女とも有 意な減少を示した\%皮下脂肪厚に注目し， 3 週 後が次のクール開始の 1 週間前となるため, 次 のクール実施の是非を判断する意味からも化療 前と化療後 3 週の変動量, すなわち『\%皮下脂 肪厚変動量』を基準変数とした。説明変数は, 特性不安得点, 年齢, 化療回数, 嘔気日数, 累 積嘔吐回数, 発熱日数, 発熱の最高値, 平均 $\%$ 食事摂取量(化療後 3 週間) の 8 変数とし, 化療 後 3 週間までの資料が得られた18例で分析した.

重回帰分析の結果は図 6 のとおりで, 重回帰 式に採択されたのは平均％食事摂取量のみであ り, 標準偏回帰係数(以下, bs という)は-0.521 $(\mathrm{p}<0.05)$ であった．次いで平均\%食事拱取量 を基準変数とし, 残りの 7 変数を説明変数とし
て再び重回帰分析を実施した，平均％食事摂取 量に対しては, 嘔気日数が負の最も強い影響を 示し $(b s=-0.536)$, 次いで累積嘔吐回数 $(b s=$ $-0.360)$, 特性不安得点 $(\mathrm{bs}=-0.334)$ そして 発熱の最高值 $(\mathrm{bs}=-0.238)$ とすべて負の影響 を及ぼしていた。またこれらの説明変数のうち, 嘔気日数と累積嘔吐回数には相関があった $(\mathrm{r}=$ $0.554)$.

\section{IV. 考察}

本研究に用いた 7 栄養指標のなかで, 身体構 成成分の和である体重は体脂肪や体蛋白の変動 を間接的に示すものであり, 癌化学療法の場合 は, 大量の補液や腎機能の低下などにより, 水 分出納が体重に影響を及ぼすことが多い。この ため体重の変動だけで栄養状態を評価するのは 適切ではない.しかし\%標準体重が80～90\%で は軽度，70８0\%では中等度，70\%以下では高 度の筋蛋白の消耗が存在するといわれており 18), これは対象患者での結果とよく一致して いる. 例えば女性死亡事例では化療前の\%標準 体重が68\%であり, 男性死亡事例では化療前87 \%が78\%にまで減少している.このように死亡 事例では中等度〜高度の筋蛋白消耗状態であっ たことがわかる。これより，体重による化療の 栄養状態の安全域を推定する場合,「\%標準体 重は $90 \%$ 以上であること」が望をしく，なおか つ化療後の急激な体重減少もリスクの 1 つとい える。

次に脂肪の指標である\%皮下脂肪厚は女性が 目立って低值であった．本研究では例数が少な く同一患者が化療を重䄈ることで栄養指標がど

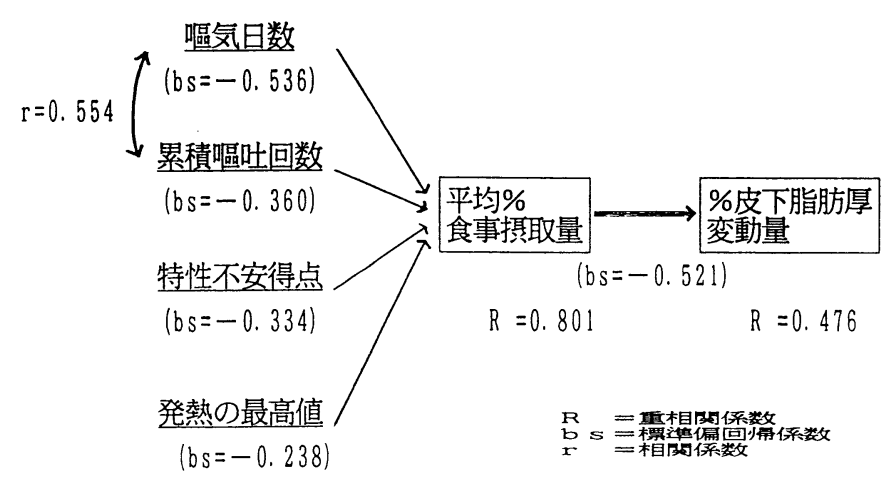

図 6 皮下脂肪厚変動の要因 
のように低下していくかをみることはできなかっ たが， 3 週後の低值は次のクールの開始でさら に減少することが予測され，女性の化療による 貯蔵脂肪減少の推移は患者観察の重要なポイン トになると考えられる。なぜなら％皮下脂肪厚 に招いても，その80 90\%が軽度，60 80\%が 中等度, $60 \%$ 以下が高度の体脂肪の消耗状態と 考光られて抒り 18$)$ ，女性の 3 週後の平均值は 高度消耗に近い值といえる。体脂肪の消耗した 女性患者では，特に上腕での皮膚のたるみが顕 著で，弾力性に乏しく皮膚表面のつやはなくザ ラザラとしていた．しかし男性の％皮下脂肪厚 は，脂肪の消耗は認められず化療後の皮下脂肪 厚の減少には性差があった。これは重回帰分析 の結果より, 皮下脂肪厚の変動量は食事の摂取 量に起因していることが判明しており，そして 食事摂取量では有意に女性が低值であったこと と一致する．\%皮下脂肪厚の化療前の完全限界 は，男性で $80 \%$ ，女性で60\%が妥当かと考兄ら れる．ただし特に男性のいわゆる筋肉質の患者 では皮下脂肪厚が薄いことから，上腕筋囲と合 わせて判断することが必要である。

$\%$ 上腕筋囲は少数例を除き，大きな変動は示 さなかった。しかし死亡事例は特に化療前から 化療後 1 週の減少が他患者より際立っており, 抗癌剂投与により急激に栄養状態が低下し，こ れがその後の病状悪化を助長したものと考光ら れる。

握力と上腕筋囲は化療前後でかなりの相関が あることから, 握力の変動は筋蛋白量の変動の 良い指標となり，また患者の「自覚的体力」の 指標になるといえる.

$\mathrm{Hb}$ の変動は栄養状態の変動といらよりも骨 䯣抑制の影響が強いと考㝋られた。しかし患者 の自覚する倦怠感はHbの低下によって強まり, 輸血などの処置によって改善することが多く, $\mathrm{Hb}$ の変動を注意深く観察することは患者の自覚す る体力喪失感を客観的に把握することの手段と なる。

また従来臨床で栄養指標として用いられてい るTPおよびAlbは平均值では正常範囲内であった。

このように身体計測に基づく栄養指標では％ 標準值が中等度以上の消耗状態を示しているの
に対し，TPおよび $\mathrm{Alb}$ の平均值は正常範囲内 であった。これは特にAlbは 4 週間といら非常 に長い半減期のため ${ }^{19)}$ ，急速に変化する栄養 状態に対してはその変動を反映していないこと になる。つまり従来栄養の指標とされていたTP やAlbなどで示される栄養状態の変化を, 身体 計測による指標を用いることでより早期に把握 し，早期に栄養補給の手段を講じることができ る.これにより化療を受ける患者の全身状態を 良好に保ち, 治療効果を向上させ, 患者が自覚 的に強い体力喪失感を持たなくなるであろう.

さらに重回帰分析の結果から, 嘔気日数, 累 積嘔吐回数, 特性不安得点㐨よび発熱の最高值 は平均\%食事摄取量にマイナスの影響を与え, 平均 $\%$ 食事摄取量は\%皮下脂肪厚変動量に影響 を及济していることがわかった。つまり，「嘔 気持続日数を短く, 嘔吐回数は少なく, 特性不 安得点は低く, 発熱しないで食事摂取量を増す ようにすれば，皮下脂肪は減少しない」と，推 測できる.このうち嘔気・嘔吐は抗癌剤投与日 の急性のものに対しては制吐剂が有効とされて いるが，投与後数日続くものはその発症のメカ ニズムがはっきりして扔らず，制吐剤の効果は 薄い。嘔気・嘔吐の遅延には精神的因子の関与 が考光られ，不安の強いもの活ど症状が強い傾 向にあることからも4), 不安の軽減が第一とな る.この意味から, 治療前に看護婦がオリエン テーションを実施することにより，患者に先の 見通しを与えることは意義あるものと考える. また嘔気・嘔吐時などに背中をマッサージし， 励すすことなどのケアを通じて，患者を心理面 から支える姿勢を示していくことも大切である う。ささら化療を受けた患者にとって摂取しや すいといわれている食品 ${ }^{11)}$ を紹介したり，準 備したりすることで, 少しずつでも食べようと する気力と食べられるといら自信を患者に持た せることも必要である。

以上より癌化学療法中の患者の栄養状態を良 好に保持するためには，嘔気・嘔吐を軽減し， 不安の強い患者に対してはその軽減を図るよう に援助し, 白血球数減少時のらがい, 手洗いな どの基本的な感染予防方法を患者自ら実施する ように働きかけ，これにより十分な食事摄取が 
維持できるような看護援助方法が必要であると いえる。

本研究に用いた皮下脂肪厚などの身体計測に よる栄養指標は, 化療中の患者の短期間の栄養 状態の変化を反映する，有効な方法のらちの 1 つであることが示唆された. 特に死亡した 2 事 例の体重, 皮下脂肪厚, 上腕筋囲が化療前から 低い值であり，化療の開始によってさらに急激 に低下し，短期間で死亡に至ったことを合わせ て考えてみると，化療前および化療期間中の患 者の栄養状態を定期的に評価していくことは， 患者の安全を守るために極めて重要である。そ して前述したような援助方法で栄養状態を悪化 させないようにするとともに，悪化が見られた 場合には早期に対応することで, 化療は安全に 実施されることになると考えられた。

\section{謝 辞}

本研究に御協力下さいました国立がんセンター 呼吸器内科スタッフの皆様に心より御礼申し上げ ます. また, 千葉県横芝町役場の皆様の御協力で, 住民検診の場で身体計測を実施させて頂きました ことを感謝いたします。

本研究の一部は, 第 9 回日本看護科学学会学術 集会(大阪)に扔いて発表した.

\section{引用文献}

1 ) 西條長宏, 藤田次郎：癌化学療法の進歩, 58 -68頁, メジカルビュー社, 1986.

2 ) Alan Coates, Suzanne Abraham, et al.: On the Receiving End-Patients Perception of the side effects of Cancer Chemotherapy, Eur. J. Cancer Clin. Oncol., 19 (2), 203-208, 1983.

3 ）沢村のり子, 船木裕子, 高橋幸子, 他：CD DP投与症例における消化器症状に対する Metoclopramide (プリンペラン)の効果, 癌 之化学療法, 12 (4), 943-946, 1985.

4 ) 西條長宏, 末舛恵一: 癌化学療法と消化器症 状対策, 治療, 67 (9) , 1841-55, 1985.

5 ) Marlene L. Black, Betty B. Gallucci, et al. : The nutritional assessment of patients receiving cancer chemotherapy, Oncology Nursing
Forum, 10 (2), 53-58, 1983.

6 ）田口鐵男 : 癌患者と栄養, 綜合臨床, 30 (10), 2519-23, 1981.

7 ) Albert Barrocas, Geoge E. Bain et al. : Nutritional Assessment: Indications and applications, J. National Medical Association, 72 (5) , 497-501, 1980.

8 ) Scwarz G. F, et al . : Combined parenteral hyperalimentation and chemothetapy in the treatment of disseminated solid tumor, Amer. J. Surg., 121, 169-178, 1971.

9 ) 西平哲郎, 平山克, 秋本実, 葛西森夫：栄養 状態と免疫能, 医学のあゆ久, 120 (5), 396-402, 1982.

10）数間恵子, 佐藤禮子, 石黒義彦：老人におけ る栄養状態評価指標としての上腕計測値の検 討, 日本看護科学会誌, 8 (1), 9-16, 1988.

11）高橋幸子, 沢村のり子, 他：シスプラチン投 与を受ける患者へのよりよい看護を目指して, 看護学雑誌, 49 (2)：185-188，1985.

12）金昌雄, 岡田正, 井村賢治, 他：身体計測, 医学のあゆみ, 120 (5), 387-395, 1982.

13）佐藤信昭, 佐藤真, 松原要一, 他：栄養状態 の筋力に及ぼす影響について，外科と代謝・ 栄養, 19 (3), 365-371, 1985.

14）船川幡夫：肥満とやせの判定基準について, 厚生の指標，34 (2), 3-9, 1987.

15）厚生省保健医療局健康増進栄養課編：昭和 63 年版 国民栄養の現状 (昭和61年国民栄養調 査成績)第一出版, 1988 .

16）文部省体育局：昭和 60 年度 体力 - 運動能力 調查報告書, 273-274, 1986 。

17) Spielberger C. D. , Gorsuch R. L. et al. : Manual for the state-trait anxiety inventory, Palo Alto, Calif: Consulting Psychologists Press. 1970.

18) George L. Blackburn and Paul A. T. : Nutritional assessment of the hospitalized patients, Med. Clin. North Amer. , 63 (5) , 1103-1115, 1979.

19）弓狩康三: 栄養アセスメントの展望, 栄養了 セスメント, 4 (2), 139-149, 1987. 